DOI: https://doi.org/10.47405/mjssh.v5i8.465

\begin{tabular}{|c|c|}
\hline 1. 1.54 & Malaysian Journal of Social Sciences and Humanities (MJSSH) \\
\hline $\begin{array}{c}\text { Malaysian Journal of } \\
\text { solal sciences and }\end{array}$ & Volume 5, Issue 8, August 2020 \\
\hline (MJ-SSH) & e-ISSN : 2504-8562 \\
\hline & $\begin{array}{l}\text { Journal home page: } \\
\text { www.msocialsciences.com }\end{array}$ \\
\hline
\end{tabular}

\title{
Barriers in Purchasing Green Cosmetic Products Among Indonesian Women
}

\author{
Sahda Nabilah Kurnia ${ }^{1}$, Lidia Mayangsari ${ }^{1}$ \\ 1School of Business and Management, Bandung Institute of Technology, Indonesia \\ Correspondence: Sahda Nabilah Kurnia (sahda_nabilah@sbm-itb.ac.id)
}

\begin{abstract}
Nowadays, many companies sell products that they claim as 'green' cosmetics to reach public demand and attention. Yet, women are starting to be concerned about green cosmetics because they wonder if it does bring sustainability and worth the claim. This research aims to analyze women's barrier factors in purchasing green cosmetics in Indonesia. This research target population is women who live in Jakarta, and Bandung, ranging from 18-34 years old, tend to use cosmetics daily and know about green cosmetics in general. The researcher uses a quantitative approach that uses 235 sample sizes and using probability sampling and questionnaire to collect the data. The data was analyzed using SmartPLS 3.0 with confirmatory factor analysis (CFA). The results show that the value barrier, usage barrier, risk barrier, tradition barrier, and image barrier positively influenced the purchase intention of green cosmetics products. The findings of this study can help green cosmetics brands in Indonesia sell their products to be accepted in the market.
\end{abstract}

Keywords: barriers, green cosmetic, green purchase behaviour

\section{Introduction}

Cosmetic is defined as a substance to enhance or to improve the internal and external appearance of the body (Sharma, Gadiya and Dhanawat, 2020). Nowadays, women are more aware of health and safety, have a positive consumption attitude to make decisions and choices, and demand extensive product knowledge (Pudaruth, Juwaheer, and Seewoo, 2015). Females who aged 18-34 years old are starting to worry with the ingredients content in their cosmetic product when they want to buy a particular skincare for their consumption (Martinko, 2017). They are already acknowledging the risk of using cosmetics that contain chemical ingredients that have a negative impact on their health. They want to avoid top lists of chemicals that have been used in common cosmetics such as parabens, sulfates, and synthetic fragrances (Kinonen, 2016; D'Adamo, 2015).

To respond environmental regulators and consumers demand, there are many companies and suppliers that are attempting to follow this green trend by starting to design, develop, and selling product that they claim as 'green' cosmetic to reach competitive advantage based on this differentiating factor, and started looking for fresh ways to grasp public demand and attention nowadays (Green Choices, 2012; Phau and Ong, 2007; Zinkhan and Carlson, 1995). With the go-green campaign, Indonesia also promotes the concept of environmentally friendly cosmetic products (Riani, 2019). There are already several local green cosmetics, which are new players in Indonesia who supervise and pay attention to the entire process of making their products so that they do not have a negative impact on the environment (Harpers Bazaar, 2017). 
Even though the companies that sell green products are increasing promptly, concern for green companies has also increased among consumers (The Economist, 2012). Women are wondering if green cosmetics do bring sustainability to the entire industry because there are a lot of green cosmetics offerings appearing on the market currently (Denise Herich, 2018). Skin Inc stated that $13 \%$ of massmarket drug consumers, $14 \%$ of specialty drug and grocery shoppers, $17 \%$ of department store customers are not satisfied with the green beauty products offered (Urbanowicz, 2015). There are several barrier factors in purchasing green products, which are price, trust, product attribute, certification, and product availability (Joshi and Rahman, 2015).

Consumers have a tendency to assume that green products are more expensive, even if they have not seen the product (Clean cult, 2019). Retail Me Not conducted a survey and identified that 4 out of 5 consumers believe that four out of five customers found that green goods are more costly than nongreen goods (Prnewswire.com, 2015). From figure 1.1, it shows that there are reports from many customers about personal preferences for environmentally friendly items, but most of the respondents report putting aside this preference by buying the cheapest products, namely $27 \%$ in Latin America, $33 \%$ in the Asia Pacific, 35\% in Europe, 36\% in the Middle East and Africa and $48 \%$ in North America (Saylor, 2020). Report from 10 studies shows that higher prices exceed ethical considerations and widen the attitude-behavior gap in purchasing green products (Connell, 2010; Gleim et al., 2013; Vermeir and Verbeke, 2006).

Ad Age conducted a survey and interviewed millennials by asking them about green brands. More than $50 \%$ of the respondents couldn't name any brand that continually promotes the green movement. The issue that millenials currently face with green products are very limited and hard to look for. Green products are not easy to find because it's not always available like other conventional competitors and most millennials do not necessarily want to go to the online small shop, farmers market, or even find out by themselves (Lupberger, 2017).

In 2017, natural cosmetics sales in the United States decreased by 1.2 percent from 2016. There are many consumers who have a lack of trust in brands that inform their products are natural (Nielsen.com, 2018). The consumer feels like the brand is not delivering the claim of safety and effects of natural cosmetics (Klaschka, 2016). This is referred to as greenwashing or the process of convincing the wrong impression or providing misleading information about a company's products to make it sound more "eco-friendly" (Investopedia, 2020). Hence, more and more consumers are questioning the company's motives for greening. They are not sure about the attributes and features of green products, as well as doubting the benefits and performance of the environment (Consulting, 2010).

Cleancult (2019) did an interview and asked millennials who are ranging from 18-30 years old and asked their thoughts in green brands. Shockingly, the common answers were a trend. They said that the quality of current green products that are available on the market was not that good. Studies also have found that many consumers were skeptical because they did not entrust information about the certifications, labeling, and manufacturing that was in the product because they are afraid to buy products that have no clear certification that will damage their skin (Nittala, 2014). The main objective of this research is to analyze the women barrier factors in purchasing green cosmetics products. The result of this research is intended to help Indonesian green cosmetic brands so that the product can be accepted in the market as well as the society.

\section{Literature Review}

\section{Green Cosmetic Consumer Behavior}

According to Amberg and Fogarassy (2019), consumers are willingly buying natural cosmetics, even if those are more expensive than chemical cosmetics because they consider conserving both their own health and the environment an important factor. To summarise, consumer behavior varies from person to person due to internal factors like different psychological and emotional feelings and external factors like family preference and social and cultural status. Given that green cosmetics is a new trend with 
immature certification standards, consumer behavior can be influenced through marketing techniques on the basis of honest descriptions of product attributes and attractive promotions.

\section{Barrier Factors in Buying Green Cosmetic Product}

Barriers become determinant and regulate people's purchase behavior. Ajzen explains that The behavior will become obvious if the person can have the power and control all the factors that take part to choose willingly or not willing to behave. These factors may be internal, for instance, income, the time available to perform behavior and competence. There are also external factors which are, the tools or resources availability and anything needed to carry out the behavior. If the person cannot handle or control all the factors that support or inhibit the behavior, it causes other factors that are not adequate to forecast the behavior (Ajzen, 2005). Kushwah, Dhir and Sagar (2019) has adapted Innovation Resistance Theory to concisely study the barriers that people consider when they want to consume green products and found that usage barriers, value barriers, risk barriers, tradition barriers, image barriers are factors that inhibit if consumers want to buy green products. Therefore, the researchers will explain further about the barrier factors below.

\section{a) Value Barriers}

If a new product is contrasted with the replacement or precedent regarding the performance and worth of monetary value, and on these metrics, the new product is found significantly lower called the value barrier. To launch a brand new product, it has to increase the value to price ratio to shift the consumer's current behavior (Ram and Sheth, 1989). Value barriers emerge, leading to perceived value discrepancies of the product's alternative (Lim, Yong, and Suryadi, 2014). Green products are considered more expensive, and customers do not want to pay higher costs only for green performance (Berger and Corbin, 1992; Sriram and Forman, 1993; Prakash, 2002).

\section{b) Usage Barriers}

Usage barrier occurs as the new product is not compatible with the current use habits, trends, and workflow and can be the key resistance factor of the new product (Ram \& Sheth, 1989). Usually, consumers react to change that can disrupt their balance (Ram, 1989). Limited availability of and difficulty in accessing environmentally sustainable products were identified as other major barriers in green purchasing (Lea and Worsley, 2008; Padel and Foster, 2005). Consumers generally prefer products that are easily accessible and don't like to spend time searching for green products (Tanner and Kast, 2003; Young et al., 2010). The lack of product consistency in the green category results in the change in existing personal equilibrium (Nandi, Bokelmann, Gowdru, \& Dias, 2017).

\section{c) Risk Barriers}

Risk barrier relies on the perception of the consumer with the risk in a new product. Which means that the degree to which vulnerability is deemed essential to create a brand new product (Ram \& Sheth, 1989). In every newly launched product, there will be a possibility of uncertainty. Because of that, consumers frequently delay the product's consumption after all the uncertainty is resolved (Molesworth \& Suortti, 2002). Moreover, if the degree of risk for a newly launched product is high, then the acceptance rate will low (Ram \& Sheth, 1989). Based on Hsu \& Chen (2014), Nandi (2017), and Scalvedi \& Saba (2018) stated that lack of trust between stakeholders, such as certification places a greater risk for customers.

\section{d) Tradition Barriers}

Tradition barriers occur if there are shifts to the current customs, standards, social and family values of consumer innovation (Ram \& Sheth, 1989). Consumers already have habits, routine and established social norms and values. Some changes regarding these can lead to aversion to new products (Laukkanen, 2016). Tradition barrier is a form of psychological obstacle that can exist because of the disagreement between the current value and beliefs of buyers, instead of the real acceptance and 
relevance with product experience (Ram \& Sheth, 1989). A crucial factor for consumers that determines them not to buy green cosmetic products are lack of knowledge and awareness (Demeritt, 2002).

\section{e) Image Barriers}

Image barrier occurs if any detrimental association is identified among brand, new product, and current product line (Ram \& Sheth, 1989). Therefore, image barriers have the ability to scale if customers associate the new product with its current heritage then it will be image barriers (Molesworth \& Suortti, 2002). Image barrier may impact a new product 's intention and user behaviour. Image barriers involve perceived skepticism. For instance, mistrust of the product that is available in the market (Hsu \& Chen, 2014; Misra \& Singh, 2016).

\section{Conceptual Framework and Hypotheses}

Figure 1 shows this research conceptual framework which has been developed by Kushwah, Dhir and Sagar (2019). The conceptual framework depicts the relationship between value barriers, usage barriers, risk barriers, tradition barriers, and image barriers towards the purchase intention of green cosmetic products.

Figure 1: Conceptual Framework

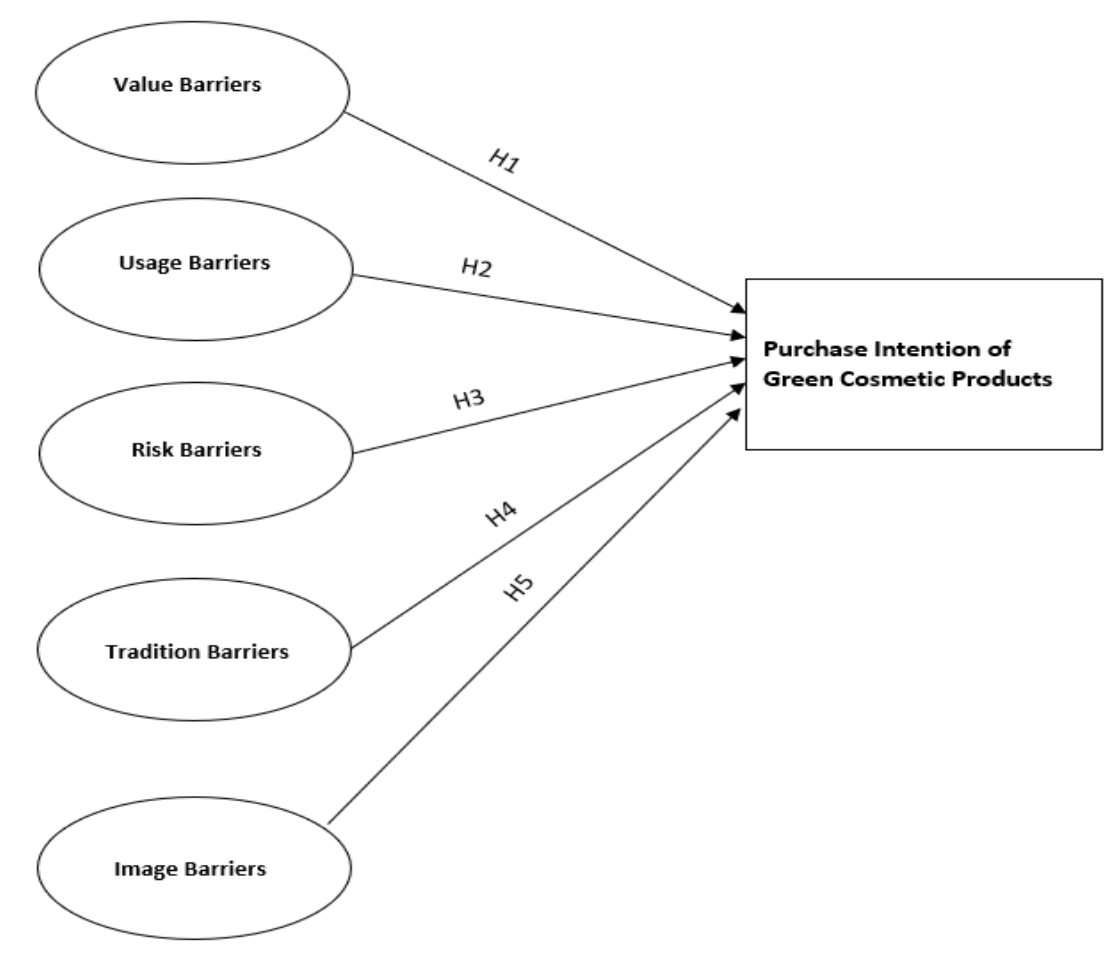

Based on the literature review and conceptual framework, the hypotheses are:

H1: Value barriers have a positive influence towards purchase intention in green cosmetic products.

H2: Usage barriers have a positive influence towards purchase intention in green cosmetic products.

H3: Risk barriers have a positive impact towards barriers of green cosmetic products. 
DOI: https://doi.org/10.47405/mjssh.v5i8.465

H4: Tradition barriers have a positive impact towards purchase intention in green cosmetic products.

H5: Image Barriers have a positive impact towards barriers of green cosmetic products.

\section{Methodology}

\section{Research Design}

This research is using a quantitative approach by dealing with the quantification and testing variables to achieve results. It also requires the usage and analysis of numerical data by using statistical methods (Leedy and Ormrod, 2001; Williams, 2011). Quantitative approach is used for calculating the influence of barrier factors towards green cosmetic products. The researcher is using a survey method to collect the data by using questionnaires. This research is using confirmatory factor analysis (CFA) for testing the variables commonality hypotheses among variables (Hoyle, 2000).

\section{Population}

This research target population are females who live in Jakarta and Bandung, ranging from 18- 34 years old, tend to use cosmetics on a daily basis, and know about green cosmetics in general.

\section{Sampling Procedures}

The sampling technique for this research is non- probability sampling, specifically in purposive sampling. Purposive or judgmental sampling is a method where particular settings are intentionally chosen to provide information that is relevant and which can not be obtained from other choices (Maxwell, 2013). Sample size indicates the number of items that will be used in the study. This research sample size is 200 respondents. The sample size for this research is based on Malhotra (2010) that have range 200-400 respondents for marketing study.

\section{Data Collection}

Questionnaire design defined as a process or method of creating a template and questions in the survey to collect data from respondents. This research questionnaire design will be constructed according to previous studies. After the questionnaire design is fixed, the questionnaire will be using google form and distributed through online messenger and email. The operational variable of the questionnaire will be explained further in Table 1. It describes the questionnaire variable or constructs and the item or the question for the questionnaire. The questionnaire will be using the Likert scale from 1-5. It means that a 1-point scale defines as strongly disagree, and 5-point Likert range defines strongly agree.

Table 1. Distribution of Respondent Demographics

\begin{tabular}{lll}
\hline Variable & Category & Frequency (\%) \\
\hline Gender & Female & $235(100 \%)$ \\
Domicile & Jabodetabek & $184(69.4 \%)$ \\
& Bandung & $81(30.6 \%)$ \\
& High School & $205(87.20 \%)$ \\
& Bachelor Degree & $26(11.1 \%)$ \\
Level of Education & Master Degree & $2(0.7 \%)$ \\
\hline
\end{tabular}



DOI: https://doi.org/10.47405/mjssh.v5i8.465

\begin{tabular}{lll}
\hline & Doctoral Degree & $1(1 \%)$ \\
& College Student & $228(86 \%)$ \\
& Employee & $18(6.8 \%)$ \\
& Freelancer & $5(1.9 \%)$ \\
Occupation & Entrepreneur & $8(3 \%)$ \\
& Intern & $2(1,2 \%)$ \\
& Housewife & $3(1.1 \%)$ \\
Frequency on Purchasing & Once in > 6 months & $93(40 \%)$ \\
Prganic Personal Care & Once in 6 months & $45(20 \%)$ \\
& Once in 3 months & $24(11 \%)$ \\
Store Preferences of & Never & $68(29 \%)$ \\
Purchasing Organic & Online Store & $95(35.9 \%)$ \\
& Offline Store & $40(15.1 \%)$ \\
\hline
\end{tabular}

In value barriers, there are three items and one indicator. The indicators depict the high price of green cosmetic products (Torres-Ruiz, Vega-Zamora, and Parras-Rosa, 2018; Krishna and Balasubramanian, 2018). In usage barriers, there are three items and two indicators. The indicator depicts the limited variety and lack of availability (Seyed Abolhasan Sadati et al. 2010; Nandi et al., 2017). In risk barriers, there are four items and two indicators. The indicator depicts a lack of trust in the stakeholders and doubts regarding certification/ labeling (Krishna and Balasubramanian, 2018). In tradition barriers, there are four items and two indicators. The indicator depicts satisfaction with conventional products and a lack of knowledge towards green cosmetic products (Nandi et al., 2017; Torres-Ruiz, VegaZamora, and Parras-Rosa, 2018; Hoppe, Vieira and Barcellos, 2013). In image barriers, there are three items and one indicator. The indicator depicts perceived skepticism (von Meyer-Höfer et al., 2015; Nandi et al., 2017; Misra \& Singh, 2016).

\section{Data Analysis}

This research is using confirmatory factor analysis (CFA). CFA is a method for quantitative data that enables an assessment of the fit among conceptualized theory models and the data that has been observed that determine the hypothesized causal relationships between the indicator variables that have been found the latent factors. Since the equivalent of population-level between model and data cannot be verified or proven through sample data, confirmatory factor analysis can be seen as a disconfirmatory method (Hong, 1999). The researcher is using a confirmatory factor analysis method and utilizing SmartPLS 3.0 to create the measurement model.

\section{Results}

\section{Convergent Validity}


DOI: https://doi.org/10.47405/mjssh.v5i8.465

According to Bagozzi and Yi (1988), convergent validity should be 0.5 or higher to make the value accepted. The measurements to verify convergent validity used in CFA are Factor Loading, Composite Reliability, and Average Variance Extracted (Hair et al., 2009).

\section{Factor Loading}

By looking at Table 2, it indicates that value barrier, usage barrier, risk barrier, tradition barrier, image barrier and purchase intention variables are valid since all the item's are higher than 0.5 .

Table 2: Factor Loading

\begin{tabular}{|c|c|c|c|c|}
\hline Construct & Code & Item & $\begin{array}{c}\text { Outer } \\
\text { Loading }\end{array}$ & Validity \\
\hline \multirow{4}{*}{$\begin{array}{l}\text { Usage } \\
\text { Barrier }\end{array}$} & UB1 & $\begin{array}{l}\text { There is a little ability for choice green } \\
\text { cosmetic products for consumption }\end{array}$ & 0.832 & Valid \\
\hline & UB2 & $\begin{array}{l}\text { The variety or range of green cosmetic } \\
\text { products products is poor }\end{array}$ & 0.930 & Valid \\
\hline & UB3 & $\begin{array}{l}\text { The reason I'm not purchasing green } \\
\text { cosmetic products because it's } \\
\text { unavailable in the shop }\end{array}$ & 0.611 & Valid \\
\hline & VB1 & $\begin{array}{l}\text { I prefer buying green cosmetic products } \\
\text { when price discounts are offered }\end{array}$ & 0.872 & Valid \\
\hline \multirow[t]{2}{*}{$\begin{array}{l}\text { Value } \\
\text { Barrier }\end{array}$} & VB2 & $\begin{array}{l}\text { When there is a special offer price for } \\
\text { green cosmetic products, I tend to buy } \\
\text { these green cosmetic products.. }\end{array}$ & 0.924 & Valid \\
\hline & RB1 & $\begin{array}{l}\text { I need to know the brand's reputation } \\
\text { well before buying a green product }\end{array}$ & 0.650 & Valid \\
\hline \multirow[t]{2}{*}{$\begin{array}{l}\text { Risk } \\
\text { Barrier }\end{array}$} & RB2 & $\begin{array}{l}\text { I prefer to buy green cosmetic products } \\
\text { if I already know the brand }\end{array}$ & 0.762 & Valid \\
\hline & RB3 & $\begin{array}{l}\text { I prefer to buy green cosmetic products } \\
\text { if I believe the product is truly green } \\
\text { from the certification on the packaging }\end{array}$ & 0.887 & Valid \\
\hline \multirow{4}{*}{$\begin{array}{l}\text { Tradition } \\
\text { Barrier }\end{array}$} & TB1 & $\begin{array}{l}\text { I am very satisfied with using } \\
\text { conventional (non-green) cosmetic } \\
\text { products so I don't have to buy green } \\
\text { cosmetic products }\end{array}$ & 0.736 & Valid \\
\hline & TB2 & $\begin{array}{l}\text { Conventional cosmetic product is } \\
\text { enough for me }\end{array}$ & 0.826 & Valid \\
\hline & TB3 & $\begin{array}{l}\text { Compared to most other people, I know } \\
\text { less about green cosmetic products }\end{array}$ & 0.796 & Valid \\
\hline & TB4 & $\begin{array}{l}\text { When it comes to green cosmetic } \\
\text { products, I really don't know a lot }\end{array}$ & 0.838 & Valid \\
\hline
\end{tabular}


DOI: https://doi.org/10.47405/mjssh.v5i8.465

\begin{tabular}{lclll} 
& IB1 & $\begin{array}{l}\text { I don't think that such products of } \\
\text { green cosmetic products really exist }\end{array}$ & 0.694 & Valid \\
$\begin{array}{c}\text { Image } \\
\text { Barrier }\end{array}$ & IB2 & $\begin{array}{l}\text { There is no difference between green } \\
\text { cosmetic products and the conventional } \\
\text { (non-green) }\end{array}$ & 0.779 & Valid \\
$\begin{array}{c}\text { Purchase } \\
\text { Intention }\end{array}$ & PI1 & $\begin{array}{l}\text { I have doubts about buying green } \\
\text { cosmetic product }\end{array}$ & 0.929 & Valid \\
products & $\begin{array}{l}\text { I plan to consume green cosmetic } \\
\text { products }\end{array}$ & 0.834 & Valid \\
& PI3 & I would buy green cosmetic products & 0.920 & Valid \\
\hline
\end{tabular}

\section{Construct Reliability \& Validity}

According to Bagozzi and Yi (1988), it's obligated to look at Composite Reliability and Cronbach's Alpha if we want to measure the reliability and validity of a construct. The composite reliability must be 0.7 or higher. For the cronbach alpha, it should be more than 0.6. Besides that, the Average Variance Extracted (AVE) should be 0.5 or higher. Table 3 implies that all the variables are valid because the cronbach alpha is more than 0.6 , the composite reliability is more than 0.7 and the AVE is more than 0.5 .

Table 3: Construct Reliability \& Validity

\begin{tabular}{|l|c|c|c|}
\hline & Cronbach's Alpha & Composite Reliability & $\begin{array}{c}\text { Average Variance } \\
\text { Extracted (AVE) }\end{array}$ \\
\hline Usage Barrier & 0.742 & 0.840 & 0.644 \\
\hline Value Barrier & 0.764 & 0.893 & 0.807 \\
\hline Risk Barrier & 0.703 & 0.814 & 0.596 \\
\hline Tradition Barrier & 0.816 & 0.876 & 0.640 \\
\hline Image Barrier & 0.763 & 0.846 & 0.651 \\
\hline Purchase Intention & 0.870 & 0.921 & 0.795 \\
\hline
\end{tabular}

\section{Discriminant Validity}

Quoted from Fornell and Larcker (1981), the "square root" of AVE of each latent variable should be greater than the correlations among the latent variables. By looking at Table 4, the square root of AVE of each latent is greater than the correlations among the latent variables, which means that all the variables are valid.

Table 4: Discriminant Validity Fornell-Larcker

\begin{tabular}{lcccccc} 
& $\begin{array}{c}\text { Image } \\
\text { Barrier }\end{array}$ & $\begin{array}{c}\text { Purchase } \\
\text { Intention }\end{array}$ & $\begin{array}{c}\text { Risk } \\
\text { Barrier }\end{array}$ & $\begin{array}{c}\text { Tradition } \\
\text { Barrier }\end{array}$ & $\begin{array}{c}\text { Usage } \\
\text { Barrier }\end{array}$ & $\begin{array}{c}\text { Value } \\
\text { Barrier }\end{array}$ \\
\hline Image Barrier & $\mathbf{0 . 8 3 9}$ & & & & & \\
\hline
\end{tabular}




\begin{tabular}{lcccccc}
\hline Purchase Intention & -0.041 & $\mathbf{0 . 8 8 3}$ & & & & \\
Risk Barrier & -0.023 & 0.249 & $\mathbf{0 . 7 7 2}$ & & & \\
Tradition Barrier & 0.126 & -0.429 & -0.079 & $\mathbf{0 . 8 0 4}$ & & \\
Usage Barrier & -0.035 & 0.623 & 0.255 & -0.261 & $\mathbf{0 . 8 9 4}$ & \\
Value Barrier & -0.003 & 0.732 & 0.249 & -0.451 & 0.493 & $\mathbf{0 . 8 6 2}$ \\
\hline
\end{tabular}

\section{Hypotheses Testing and Discussion}

Table 5 shows the hypothesis test analysis result from this research. Five hypotheses are being tested on this research regarding the influence of image, risk, tradition, usage, and value barriers towards purchase intention. Based on the results, all the hypotheses are valid since the p-value is more than 1.96, and the t- statistics is less than 0.5. Thus, value barriers (VB), usage barriers (UB), risk barriers (RB), tradition barriers (TB), and image barriers (IB) are significantly influenced by purchase intention towards green cosmetic products.

Table 5. Hypothesis Testing Result

\begin{tabular}{lccc}
\hline \multicolumn{1}{c}{ Hypothesis } & $\begin{array}{c}\text { T Statistics } \\
(|\mathbf{O} / \mathbf{S T D E V}|)\end{array}$ & P Values & Decision \\
\hline $\begin{array}{l}\text { H1 = Value barriers barriers have a positive } \\
\text { influence towards barriers in purchasing green } \\
\text { cosmetic }\end{array}$ & 2.029 & 0.043 & Accepted \\
$\begin{array}{l}\text { H2 = Usage barriers have a positive influence } \\
\text { towards barriers in purchasing green cosmetic }\end{array}$ & 3.591 & 0.000 & Accepted \\
$\begin{array}{l}\text { H3 = Risk barriers have a positive influence } \\
\text { towards barriers in purchasing green cosmetic }\end{array}$ & 2.695 & 0.007 & Accepted \\
$\begin{array}{l}\text { H4 }=\text { Tradition barriers have a positive } \\
\text { influence towards barriers in purchasing green } \\
\text { cosmetic }\end{array}$ & 2.242 & 0.025 & Accepted \\
$\begin{array}{l}\text { H5 }=\text { Image barriers have a positive influence } \\
\text { towards barriers in purchasing green cosmetic }\end{array}$ & 6.523 & 0.000 & Accepted \\
\hline
\end{tabular}

This research is conducted to find out the influence of value barriers (VB), usage barriers (UB), risk barriers (RB), tradition barriers (TB), and image barriers (IB) towards the purchase intention in green cosmetics products. For the H1, the value barrier does have a positive influence on the purchase intention of green cosmetic products. The indicator of value barriers is the high price of green cosmetic products. The p-value for H1 is 0.043 and 2.029 for the t-test. According to Berger and Corbin (1992), Sriram and Forman (1993), Prakash (2002), green products are more expensive than conventional products; thus, the customer doesn't want to expense a higher cost. Lim, Yong, and Suryadi (2014) also stated that when value barriers emerge, it may lead to perceived value discrepancies of the product's alternative. Therefore, it can be concluded that hypothesis 1 is accepted.

For the $\mathrm{H} 2$, usage barriers have a positive influence on barriers in purchasing green cosmetics. The indicator of usage barriers is limited variety and lack of availability of green cosmetic products. The pvalue for $\mathrm{H} 2$ is 0 and 3.591 for the t-test. According to Ram \& Sheth (1989) Usage barrier occurs as the new product is not compatible with the current use habits, trends, and workflow and can be the critical resistance factor of the new product. Therefore, it can be concluded that hypothesis 2 is accepted. For the $\mathrm{H} 3$, risk barriers have a positive influence on barriers in purchasing green cosmetics. The indicator for risk barriers are lack of trust to the stakeholders and doubt regarding certification/ labeling. The p- 
value for H3 is 0.007 and 2.695 for the t-test. Based on Ram \& Sheth (1989), the risk barrier relies on consumers' perception of the risk of a new product. Lack of trust between stakeholders, such as certification, places a higher risk for customers (Hsu \& Chen, 2014; Nandi, 2017; and Scalvedi and Saba, 2018). Therefore, it can be concluded that hypothesis 3 is accepted.

For the $\mathrm{H} 4$, tradition barriers have a positive influence on barriers in purchasing green cosmetics. The indicator for tradition barriers is satisfaction with conventional products and a lack of knowledge towards green cosmetic products. Refers to Ram \& Sheth (1989), tradition barrier is a form of psychological obstacle that can exist because of the disagreement between the current value and beliefs of buyers instead of the real acceptance and relevance with product experience. The p-value for $\mathrm{H} 4$ is 0.025 and 2.242 for the t-test. Therefore, it can be concluded that hypothesis 4 is accepted. For the H5, image barriers have a positive influence towards barriers in purchasing green cosmetics. The image barrier may impact a new product 's intention and user behavior. The image barriers indicator involves perceived skepticism. For instance, mistrust of the product available in the market (Henryks et al., 2014; Hsu \& Chen, 2014; Misra \& Singh, 2016). The p-value for H5 is 0 and 6.523 for the t-test. Therefore, it can be concluded that hypothesis 5 is accepted.

\section{Conclusion}

This research aims to analyze women barrier factors in purchasing green cosmetic products. The researcher found that there are five barriers regarding the purchase intention in green cosmetic products. The barriers are value barriers, usage barriers, risk barriers, tradition barriers, and image barriers. Confirmatory Factor Analysis method has been used in this research, and the result shows that all the barriers are positively influenced by purchase intention.

The researcher had proposed several recommendations based on the research results. First, to make the green cosmetic brand accepted in Indonesia, it is advisable to boost its marketing strategy to build the consumer's trust and brand awareness. After the brand already understands on executing their marketing strategy, it is recommended to tweak more information about purchase intention green cosmetic products in Indonesia. For instance, this research stated that one of the barriers to purchasing green cosmetic products is risk barriers regarding its doubt on certification/labeling. Thus, the strategy that can be done in order to increase the purchase intention regarding its risk barrier is by attaching certification on the packaging label - for example, BPOM certification.

This research is only targeted at women who are ranging from 18- 34 years old. Besides that, the data only gathered from two areas in Indonesia, which are Jabodetabek and Bandung. The respondents are also not varied since they mainly came from college students, which makes this study a limitation in the demographic aspect. Besides that, this research only discussed five barriers regarding the purchase intention of green cosmetic products. Therefore, for further investigation, the researcher should broaden the demographic aspect, such as widen the age range and population area; thus, the data results will represent more segmentation. Besides that, the researcher also can find another barrier related to green cosmetic product purchase intention.

\section{References}

Ajzen, I. (2005). Attitudes, Personality And Behavior. Maidenhead: Open University Press.

Amberg, N. and Fogarassy, C. (2019). Green Consumer Behavior in the Cosmetics Market. Resources, $8(3), 137$.

Bagozzi, R. P. \& Yi, Y. (1988). On the evaluation of structural equation models. Journal of the Academy of Marketing Science, 16(1), 74-94.

Berger, I. \& Corbin, R. (1992). Perceived Consumer Effectiveness and Faith in Others as Moderators of Environmentally Responsible Behaviors. Journal of Public Policy \& Marketing, 11(2), 7989 . 
Cleancult. (2019). Five Reasons Why Millennials Are Done With "Green" Brands|cleancult. [online] Available at: https://www.cleancult.com/blog/five-reasons-why-millennials-are-actually-donewith-green-brands [Accessed 5 Mar. 2020].

Connell, K. (2010). Internal and external barriers to eco-conscious apparel acquisition. International Journal of Consumer Studies, 34(3), 279-286.

Consulting, G. (2010). New Report: American Consumers Lead the World in Environmental Skepticism. [online] Prnewswire.com. Available at: https://www.prnewswire.com/newsreleases/new-report-american-consumers-lead-the-world-in-environmental-skepticism103520764.html [Accessed 5 Feb. 2020].

D'Adamo, A. (2015). Skin Care Industry Trends: What Women Want $\mid$ WMI. [online] Stellarising.com. Available at: https://www.stellarising.com/blog/2015/10/skin-care-industry-trends/ [Accessed 2 Feb. 2020].

Demeritt, D. (2002). What is the 'social construction of nature'? A typology and sympathetic critique. Progress in Human Geography, 26(6), 767-790.

Denise H. T. (2018). The Natural Organic Beauty Consumer: 2008-2018. [online] Global Cosmetic Industry. Available at: https://www.gcimagazine.com/marketstrends/segments/natural/TheNatural-and-Organic-Beauty-Consumer-487250721.html [Accessed 2 Feb. 2020].

Fornell, C. \& Larcker, D. (1981). Evaluating Structural Equation Models with Unobservable Variables and Measurement Error. Journal of Marketing Research, 18(1), 39.

Gleim, M., Smith, J., Andrews, D. \& Cronin, J. (2013). Against the Green: A Multi-method Examination of the Barriers to Green Consumption. Journal of Retailing, 89(1), 44-61.

Green Choices (2012). Toiletries \& cosmetics. [online] Available at: http://www.greenchoices.org/ green-living/toiletries-cosmetics [Accessed 2 Feb. 2020].

Hair, J. F. \& Black, W. C. (2009). Multivariate data analysis.(7th International Economy Edition).

Harpers Bazaar. (2017). 10 Produk Lokal Berkonsep Organik. [online] Harper's Bazaar Indonesia. Available at: https://harpersbazaar.co.id/articles/read/4/2017/3824/10-Produk-Lokal-BerkonsepOrganik [Accessed 3 Feb. 2020].

Hong, S. (1999). Latent structure of the social interaction self-statement test: an application of hierarchical confirmatory factor analysis. Psychological Reports, 84(3), 1303.

Hoppe, A., Vieira, L. M. \& Barcellos, M. D. D. (2013). Consumer behaviour towards organic food in porto alegre: an application of the theory of planned behaviour. Revista de Economia $e$ Sociologia Rural, 51(1), 69-90.

Hoyle, R. (2000). Personality Processes and Problem Behavior. Journal of Personality, 68(6), 953966.

Hsu, C. \& Chen, M. (2014). Explaining consumer attitudes and purchase intentions toward organic food: Contributions from regulatory fit and consumer characteristics. Food Quality and Preference, 35, 6-13.

Investopedia. (2020). What You Should Know About Greenwashing. [online] Available at: https://www.investopedia.com/terms/g/greenwashing.asp [Accessed 3 Feb. 2020].

Joshi, Y. \& Rahman, Z. (2015). Factors Affecting Green Purchase Behaviour and Future Research Directions. International Strategic Management Review, 3(1-2), 128-143.

Kinonen, S. (2016). Survey: Millennials Want Cleaner Beauty Products. [online] Allure. Available at: https://www.allure.com/story/millennial-women-green-beauty [Accessed 2 Feb. 2020].

Klaschka, U. (2016). Natural personal care products - analysis of ingredient lists and legal situation. Environmental Sciences Europe, 28(1).

Krishna, R. \& Balasubramanian, P. (2018). The significance of factors influencing consumer behaviour towards organic food products in Kochi. International Journal of Pure and Applied Mathematics, 119(12), 2641-2665.

Kushwah, S., Dhir, A. \& Sagar, M. (2019). Understanding consumer resistance to the consumption of organic food. A study of ethical consumption, purchasing, and choice behaviour. Food Quality and Preference, $77,1-14$.

Laukkanen, T., Sinkkonen, S. \& Laukkanen, P. (2009). Communication strategies to overcome functional and psychological resistance to Internet banking. International Journal of Information Management, 29(2), 111-118.

Lea, E. \& Worsley, T. (2005). Australians' organic food beliefs, demographics and values. British Food Journal, 107(11), 855-869. 
Leedy, P. \& Ormrod, J. (2001). Practical Research. 7th ed. Harlow, United Kingdom: Pearson Education Limited.

Lim, W., Yong, J. \& Suryadi, K. (2014). Consumers' Perceived Value and Willingness to Purchase Organic Food. Journal of Global Marketing, 27(5), 298-307.

Lupberger, R. (2017). 5 Reasons Why Millennials Don't Buy Green Brands - And A Better Way To Reach Them | Conscious Company. [online] Conscious Company. Available at: $<$ https://consciouscompanymedia.com/sustainable-business/marketing/5-reasons-millennialsdont-buy-green-brands-better-way-reach/> [Accessed 27 July 2020].

Malhotra, N. K. (2010). Marketing Research: An Applied Orientation. 6th ed. Upper Saddle River, NJ: Pearson Education.

Martinko, K. (2017). More women are buying green beauty products.[online] TreeHugger. Available at:https://www.treehugger.com/organic-beauty/more-women-are-buying-green-beautyproducts.html [Accessed 3 Mar. 2020].

Maxwell, J. (2013). Qualitative Research Design. Thousand Oaks (Calif.): SAGE Publications.

Misra, R. \& Singh, D. (2016). An analysis of factors affecting growth of organic food. British Food Journal.

Molesworth, M. \& Suortti, J. (2002). Buying cars online: the adoption of the web for highinvolvement, high-cost purchases. Journal of Consumer Behaviour, 2(2), 155-168.

Nandi, R., Bokelmann, W., Gowdru, N.V. \& Dias, G. (2017). Factors influencing consumers' willingness to pay for organic fruits and vegetables: Empirical evidence from a consumer survey in India. Journal of Food Products Marketing, 23(4), 430-451.

Nielsen.com. (2018). The Future of Beauty. [online] Available at: https://www.nielsen.com/us/en/insights/report/2018/the-future-of-beauty/ [Accessed 3 Feb. 2020].

Nittala, R. (2014). Green Consumer Behavior of the Educated Segment in India. Journal of International Consumer Marketing, 26(2), 138-152.

Padel, S. \& Foster, C., (2005). Exploring the gap between attitudes and behaviour. British Food Journal, 107(8), 606-625.

Phau, I. and Ong, D. (2007). An investigation of the effects of environmental claims in promotional messages for clothing brands. Marketing Intelligence \& Planning, 25(7), 772-788.

Prakash, A. (2002). Green marketing, public policy and managerial strategies. Business Strategy and the Environment, 11(5), 285-297.

Prnewswire.com. (2015). 4 in 5 Consumers Think Eco-Friendly Products Cost More "Green". [online] Available at: https://www.prnewswire.com/news-releases/4-in-5-consumers-think-eco-friendlyproducts-cost-more-green-300061649.html [Accessed 2 Feb. 2020].

Pudaruth, S., Juwaheer, T. \& Seewoo, Y. (2015). Gender-based differences in understanding the purchasing patterns of eco-friendly cosmetics and beauty care products in Mauritius: a study of female customers. Social Responsibility Journal, 11(1), 179-198.

Ram, S. \& Sheth, J. N. (1989). Consumer resistance to innovations: the marketing problem and its solutions. Journal of consumer marketing.

Riani, A. (2019). 6 Merek Skincare Lokal dengan Klaim Natural, Ada Favorit Anda?. [online] liputan6.com. Available at: https://www.liputan6.com/lifestyle/read/4082152/6-merek-skincarelokal-dengan-klaim-natural-ada-favorit-anda [Accessed 6 Feb. 2020].

Sadati, S. A., Sadati, S. A., Fami, H. S. \& Del, P. T. T. (2010). Survey consumer attitude toward barriers of organic products (op) in Iran: A case study in Gorgan City. World Applied Sciences Journal, 8(11), 1298-1303.

Saylor (2020). Market Barriers to Sustainability Products. [online] Available at: https://saylordotorg.github.io/text the-sustainable-business-case-book/s10-02-market-barriersto-sustainabil.html [Accessed 7 Feb. 2020].

Scalvedi, M. \& Saba, A. (2018). Exploring local and organic food consumption in a holistic sustainability view. British Food Journal, 120(4), 749-762.

Sharma, G., Gadiya, J. \& Dhanawat, M. (2020). Textbook Of Cosmetic Formulations. India.

Sriram, V. \& Forman, A. (1993). The Relative Importance of Products' Environmental Attributes: A Cross-cultural Comparison. International Marketing Review, 10(3), 51-70.

Tanner, C. \& Wölfing Kast, S. (2003). Promoting sustainable consumption: Determinants of green purchases by Swiss consumers. Psychology \& Marketing, 20(10), 883-902. 
DOI: https://doi.org/10.47405/mjssh.v5i8.465

The Economist. (2012). Busted trust. [online] Available at: https://www.economist.com/newsbook/2012/01/23/busted-trust [Accessed 2 Feb. 2020].

Torres-Ruiz, F.J., Vega-Zamora, M. \& Parras-Rosa, M. (2018). False barriers in the purchase of organic foods. The case of extra virgin olive oil in Spain. Sustainability, 10(2), 461.

Urbanowicz, N. (2015). Survey: 54 of Women Want Skin Care to Be All Natural. [online] Skin Inc. Available at: https://www.skininc.com/skinscience/ingredients/Survey-54-Percent-of-WomenWant-All-Natural-Products-321263321.html [Accessed 2 Feb. 2020].

Vermeir, I. \& Verbeke, W. (2006). Sustainable Food Consumption: Exploring the Consumer "Attitude - Behavioral Intention" Gap. Journal of Agricultural and Environmental Ethics, 19(2), 169-194.

Von Meyer-Höfer, M., Olea-Jaik, E., Padilla-Bravo, C. A. \& Spiller, A. (2015). Mature and emerging organic markets: Modelling consumer attitude and behaviour with partial least square approach. Journal of Food Products Marketing, 21(6), 626-653.

Williams, C. (2011). Research Methods. Journal of Business \& Economics Research (JBER), 5(3).

Young, W., Hwang, K., McDonald, S. \& Oates, C. (2010). Sustainable consumption: green consumer behaviour when purchasing products. Sustainable Development, 18(1), 20-31

Zinkhan, G. \& Carlson, L. (1995). Green Advertising and the Reluctant Consumer. Journal of Advertising, 24(2), 1-6. 